DENT, C.E. (1970) Calcium metabolism in sarcoidosis. Postgraduate Medical Journal, 46, 471.

JAMES, D.G. (1959) Ocular sarcoidosis. American Journal of Medicine, 26, 331.

Lawson, D.E.M., Fraser, D.R., Kodicek, E., Morris, H.R. \& Williams, D.H. (1971) Identification of 1, 25-dihydroxycholecalciferol, a new kidney hormone controlling calcium metabolism. Nature. London, 230, 228.
MAcGregor, G.A. (1973) Parathyroid disease. Lancet, ii, 33.

TAYLOR, R.L., LyNCH, H.J. \& WySOR, W.G. (1963) Seasonal influence of sunlight on the hypercalcaemia of sarcoidosis. American Journal of Medicine, 34, 221.

Winnacker, J.L., Becker, K.L. Friedlander, M., Higgins, G.A. \& MOORE, J.F. (1969) Sarcoidosis and hyperparathyroidism. American Journal of Medicine, 46, 305.

\title{
Inflammatory fibroid polyp of the ileum-a rare cause of intussusception
}

\author{
J. C. McGregor \\ M.B., Ch.B., B.Sc., F.R.C.S. \\ S. S. RAO \\ M.B., M.R.C.Path.

\begin{abstract}
Departments of Surgery and Pathology, Stobhill General Hospital, Glasgow
\end{abstract}
\begin{abstract}
Summary
A case of 'inflammatory fibroid polyp' in the terminal ileum is described. It occurred in a 38-year-old female and was associated with an ileo-ileal intussusception presenting as an acute intestinal obstruction. The macroscopic and microscopic features of this rare lesion are illustrated. It would appear to be an entity which may have been confused in the past with the haemangiopericytoma.
\end{abstract}

\section{Case history}

A 38-year-old woman was admitted to Stobhill General Hospital, Glasgow, as an emergency with a history of abdominal colic and vomiting over a period of $12 \mathrm{hr}$. She had been in good health and had had no previous operations or illness. On admission, a soft but definite swelling was noted in the right iliac fossa. It was decided that laparotomy should be performed.

\section{Operative findings}

The abdomen was opened through a right paramedian incision. The mass noted before operation proved to be an ileo-ileal intussusception through the ileo-caecal valve into the caecum and ascending colon. The intussusception was reduced with difficulty and the cause was found to be a polypoid lesion of the ileum about $20 \mathrm{~cm}$ from the ileo-caecal valve. No lymph node enlargement was noted in the mesentery. A resection of approximately $6 \mathrm{~cm}$ of ileum, containing the polypoid structure, was performed and end-to-end anastomosis accomplished.
Post-operative progress

The patient remains well to date, almost 3 years after operation.

\section{Pathology}

A segment of ileum, approximately $6 \mathrm{~cm}$ in length, with a narrow strip of mesentery attached was examined. The serosa was congested. At one place, the wall of the bowel was necrotic and a pedunculated nodule, $2.8 \mathrm{~cm}$ in diameter, protruded through. The ileum was constricted at the base of the nodule, and the wall of the gut at this point was pulled inwards (Fig. 1). The lesion on the cut surface was greyish-white in colour and appeared to consist of a firm oedematous stroma.

Microscopically, the nodule consisted of a very oedematous fibrous stroma containing numerous small blood vessels and chronic inflammatory cells (lymphocytes, plasma cells and eosinophils). The muscle fibres of the muscle coat of the bowel wall were separated owing to oedematous fibrous tissue between them (Fig. 2). Reticulin stain showed fine reticulin fibres and accentuated the presence of several vessels (Fig. 3). The histological appearances were consistent with those of the 'inflammatory fibroid polyp' described by Helwig and Ranier in 1953.

\section{Discussion}

It is well recorded in the literature that intussusception in the adult is an uncommon condition. Donhauser and Kelly (1950) collected 665 cases reported in English and American literature from 


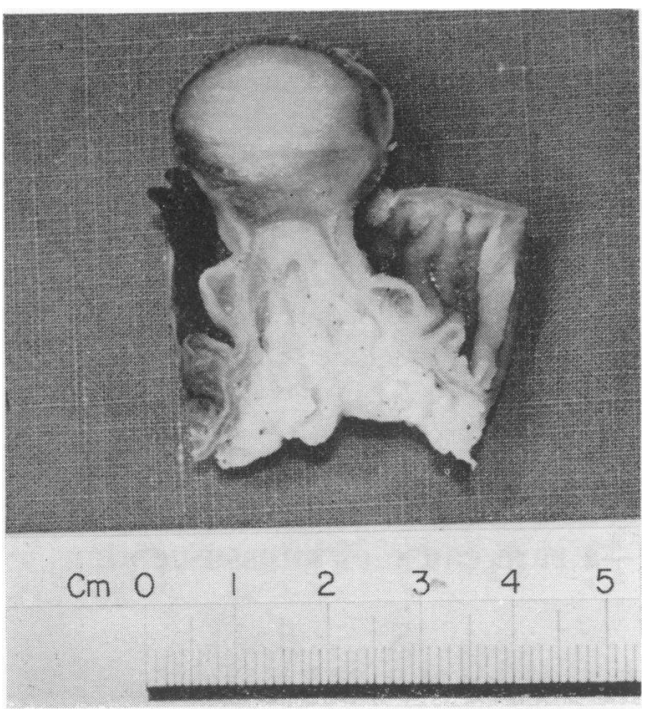

FIG. 1. Inflammatory fibroid polyp: The cut surface of the lesion showing greyish-white stroma and the wall of the gut drawn inwards.

1900 to 1942 . Sanders, Hagan and Kinnaird (1958) reviewed 1252 cases of acute intussusception in adults reported in the literature from 1892. Two thirds of these occurred in the small bowel. According to Briggs, Carpathios and Zollinger (1961),
$5-7 \%$ of all intussusceptions occur in adults and the vast majority are initiated by benign or malignant tumours. The largest individual group in any intestinal segment was found in the ileum.

Helwig and Ranier (1953) described a condition $\overrightarrow{\vec{F}}$ in the stomach which they called an 'inflammatory $\overrightarrow{0}$ fibroid polyp'. It presented a distinctive histological등 appearance with fibrous and vascular tissue and an $\overline{\bar{c}}$. inflammatory infiltrate including eosinophils. The $\widetilde{\Phi}$ authors postulated that these lesions represented $a_{0}$ reaction of connective tissue of the gastric mucosa ${ }^{\infty}$ and submucosa to some unknown inflammatory $\overrightarrow{0}$ stimulus.

Their description bears considerable resemblance $\vec{\sigma}$ to this case and also to cases described and illustratedo in the small bowel but classified as 'haemangio- $\frac{0}{3}$. pericytomas' (Stout, 1949; Smith and Swensen, 1954; Thompson, 1954; Patterson, Callow and? Ettinger, 1958; Olsen and Wellwood, 1970). The term 'haemangiopericytoma' was introduced by Murray and Stout in 1942 to describe a tumour ${ }^{\circ}$ composed of vessels set in a stroma of spindle- $\frac{}{工}$ shaped cells or round cells. These cells were thought $\overrightarrow{ }$ possibly to be derived from the pericyte-a modified $\mathbb{P}$ smooth muscle cell regulating the capillary lumen (Zimmerman, 1923). Slattery, Aronson and Lowman (1956) reviewed 'haemangiopericytoma' and noted that they had been reported in various sites in the body with a $21 \%$ incidence of malignancy. They noted fifteen intra-abdominal lesions including those

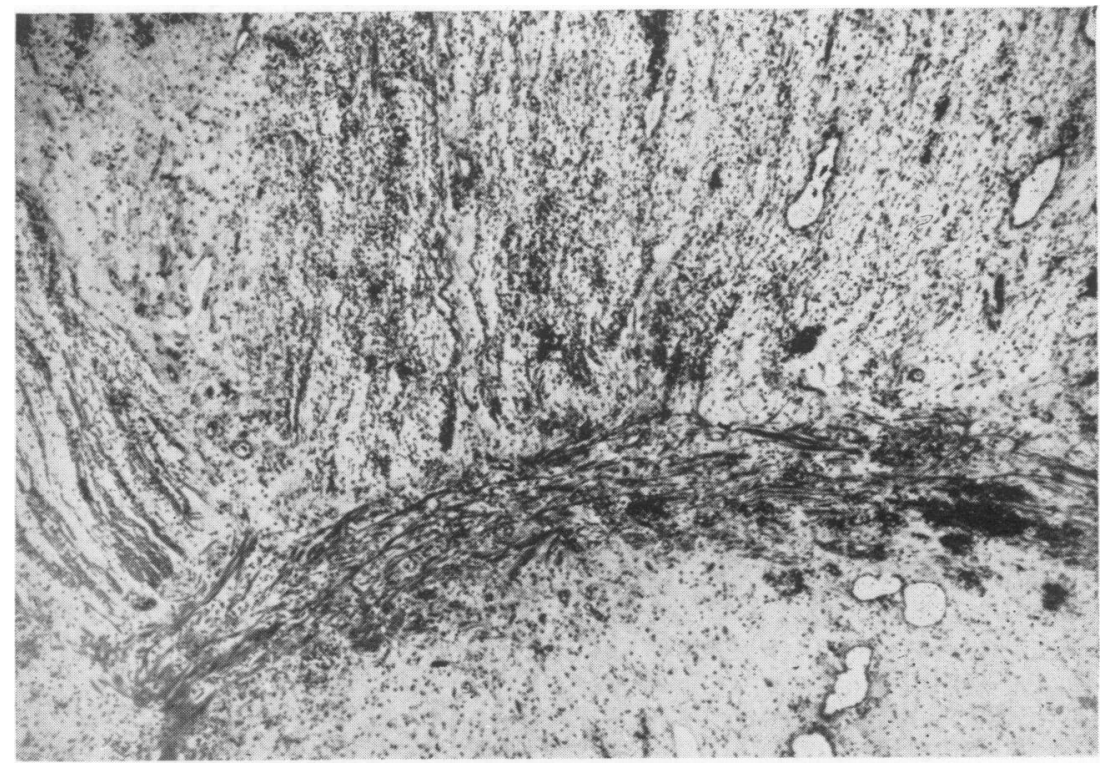

FIG. 2. Inflammatory fibroid polyp with intestinal muscle fibres separated by oedematous fibrous tissue $(\mathrm{H}$ and $\mathrm{E}, \times 14)$. 


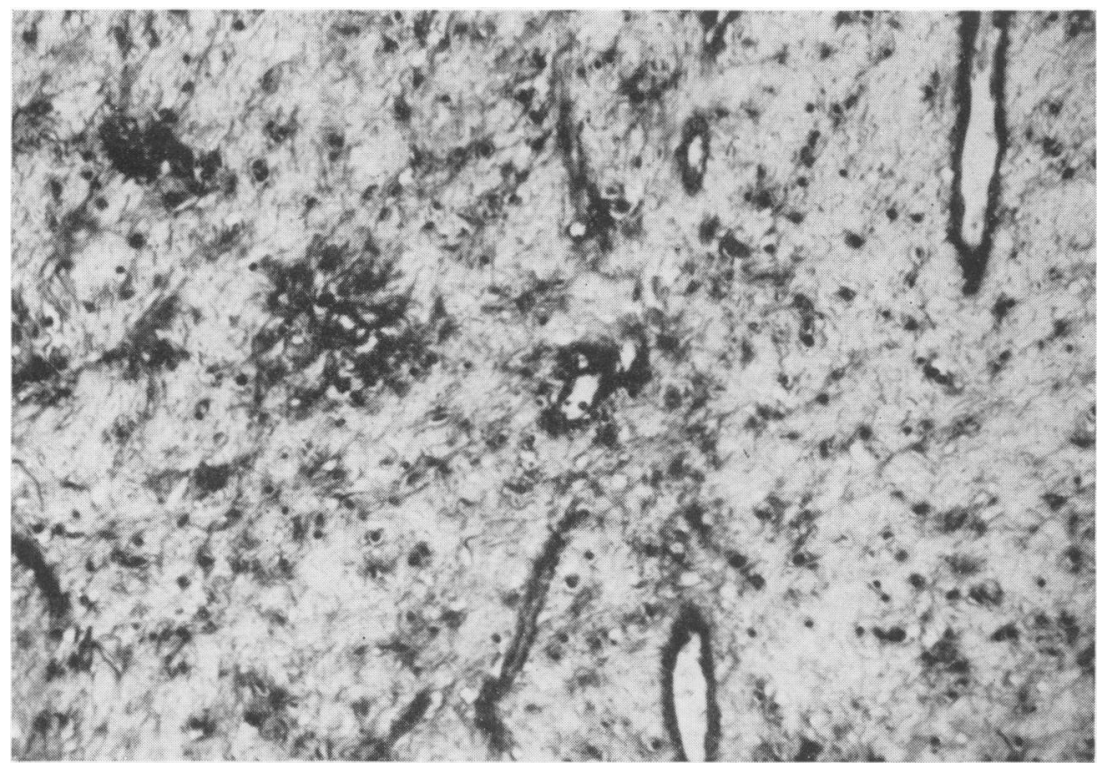

Fig. 3. Inflammatory fibroid polyp. The reticulin strain shows fine reticulin fibres and accentuates the presence of blood vessels (Gordon and Sweet's silver impregnation for reticulin, $\times 56$ ).

of Stout (1949), Smith and Swensen (1954) in the ileum, and Thompson (1954) and Patterson et al. (1958) in the jejunum. To these may be added the three cases, one ileal and two jejunal, recorded by Olsen and Wellwood in 1970.

The cases reported from the small bowel presented with symptoms of acute or subacute intestinal obstruction and required laparotomy and resection of the lesion. Intussusception was associated with the polyp in Thompson's case and in one of Olsen and Wellwood's cases. Although the latter authors called the lesion causing the intussusception a 'haemangiopericytoma' they agreed with Helwig and Ranier (1953) that the nature of this was inflammatory rather than neoplastic.

It is the opinion of the authors that 'inflammatory fibroid polyp' of the small bowel is now established as a definite entity, does not represent a neoplastic process, and should therefore not be classified as a true haemangiopericytoma.

\section{Acknowledgments}

We thank Mr I. F. Kerr, Consultant Surgeon, for allowing us to present his case and for his advice in the preparation of our paper. We thank also Mrs Nasmyth and her staff for typing the manuscript.

\section{References}

Briggs, D.F., Carpathios, J. \& Zollinger, R.W. (1961) Intussusception in adults. American Journal of Surgery, 101, 109.

Donhauser, J.L., \& Kelly, B.C. (1950) Intussusception in the adult. American Journal of Surgery, 79, 673.

HelWIG, E.B. \& RANIER, A. (1953) Inflammatory fibroid polyps of the stomach. Surgery, Gynecology and Obstetrics, 96, 355.

MurRay, M.R. \& Stout, A.P. (1942) Hemangiopericytoma. Annals of Surgery, 116, 26.

Olsen, E.G.J. \& Wellwood, J.M. (1970) Haemangiopericytoma of the small intestine. British Journal of Surgery, 57, 66.

Patterson, J.F., Callow, A.D. \& Etringer, A. (1958) The clinical patterns of small bowel tumors: a study of 32 cases. Annals of Internal Medicine, 48, 123.

ROPER, A. (1956) Intussusception in adults. Surgery, Gynecology and Obstetrics, 103, 267.

Sanders, G.B., Hagan, W.H. \& Kinnaird, D.W. (1958) Adult intussusception and carcinoma of the colon. Annals of Surgery, 147, 796.

Slattery, L.R., Aronson, S.G. \& Lowman, E.W. (1956) Review of abdominal cases. American Journal of Surgery, 91, 985.

Smith, W.P. \& Swensen, R.E. (1954) Hemangiopericytoma of the ileum. American Journal of Surgery, 87, 143.

Stout, A.P. (1949) Haemangiopericytoma. Cancer, 2, 1027.

Thompson, J.A. (1954) Hemangiopericytoma of the jejunum. Surgery, St Louis, etc., 36, 976.

Zimmerman, K.W. (1923) Der jenere Bau der Blutcapillaren. Zeitschrift für Anatomie und Entwicklungsgeschichte, 68, 29 (cited by Murray, M.R. \& Stout, A.P.). 